\title{
Improving German Listening Competence by the NURS Teaching Model
}

\author{
Nurming Saleh', Muh. Anwar², Misnawaty Usman³ \\ State Universisty of Makassar, Indonesia ${ }^{1,2,3}$ \\ Email: nurming.saleh@unm.ac.id ${ }^{1}$
}

Submitted: 05/12/2020

Revised: 16/01/2021

Accepted: 23/01/2021

$\begin{array}{ll}\text { E-ISSN : } 2579-4574 & \text { P-ISSN : 2549-7359 }\end{array}$

Abstract. Listening is a receptive language competence named as the beginning of the catching on information, and it will be helpfully on the ideas developing. This study is a classroom action research (CAR) and aimed at German listening competence increase of students by implementing the NURS teaching model. NURS is an abbreviation of Nature, Unique, Relevant, and Situational. It is a didactic, constructively, metacognitive, humanly, intercultural, instructional, and technological-based learning procedure. Kemmis and Taggar model consisting of planning, action, observation, and reflection for every cycle, was utilized to implement this CAR in the German educational department at the Faculty of Language and Literature 25 students in the second semester as the research sample with two circles. The syllabus, teaching plan, student activity sheet, and listening formative test were implemented as the research instrument. The data analyzed by using percentage techniques. The result shows that the average student's German listening competence in the first cycle is 46 . After they learned in the second, they could not be in minimum score standard 75 because their average score is 61 . Their competence percentage increased by $35.16 \%$ to 81.16 . Another important thing about using the NURS teaching model on learning German is the positive effect on the teacher's teaching skills, like management of teaching, time, and how to make students more enthusiastic during the learning process. It can be concluded that the NURS teaching model can improve the student's German listening competence in the German educational department at the Faculty of Language and Literature of Makassar State University.

Keywords: Classroom Action Research, NURS Teaching Model, German, Listening Competence

https://ojs.unm.ac.id/eralingua

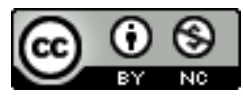

This work is licensed under a Creative Commons Attribution-NonCommercial 4.0 International License 


\section{INTRODUCTION}

German is known as one of the foreign languages studied by approximately 185 million people worldwide. According to www.dw.de, German is studied by 15.4 million people as a foreign language at a formal educations level and universities in the entire world. The German foreign ministry (Auswärtiges Amt) on the website shows that the number of German learners in Asia is 1,773,750 people. Indonesia is one of the countries in Southeast Asia that facilitates a place to learn German through several course institutions and 14 universities by the German literature, and the German educational department. Makassar State University is one of the universities in Indonesia that provides a platform for learning German through the German language education department at the faculty of language and literature. Teaching German in this department is divided into several courses that reflect the language competencies, which are Leseverstehen (listening), Hörverstehen (listening), Schreibfertigkeit (writing), and Sprechfertigkeit (speaking). In addition to these four things, students' German-language competence stands for Strukturen und Wortschatzt (grammar and vocabularies).

Teaching German at Indonesian University is based on the Indonesian National Qualification Framework curriculum (KKNI) based on an attempt to empower the learning outcomes of entrepreneurial-minded Teaching and the Common European Framework of Reference for Language (Gemeinsamer Europäische Referenzrahmen). Learning German at university is inseparable from receptive and productive language competencies. Receptive competence is from listening activities (Lesen) and listening (Hören). Both activities mean understanding a person's information contained in a text or audio. Meanwhile, productive competence is illustrated by writing (Schreiben) and speaking activities (Sprechen), which are each focused on the process of expressing ideas orally and in writing. The developing process of German-language competencies is also supported by the master of student vocabulary and grammar so that these two things can be said to be the center key to students' success in mastering the four German-language competencies.

Listening is one of the competencies of language that focuses on the students' understanding of the contained audio information. This competence is often quite complicated but sometimes also easy based on the interview results with second-semester students virtually on April 14, 2020. 18 out of 25 students said that they got problems in learning German, especially in listening competencies. They argued that listening competence was quite bored because they heard German audio with a fast spoken speed. They are not able to understand the information contained in the audio. A lack of vocabulary in German vocabulary and understanding of German tenses was also another problem. The interview results were supported by their average score in the previous semester on listening competencies of 63.25 classified as insufficient categories based on intervals and assessment criteria of the Goethe Institute.

Listening is prevailing identical to the form of a multiple-choice test and the true or false test to know the level of one's understanding of information. Based on the researcher's experience as lecturers, the enthusiasm and attractiveness of 
students to believe in their ability are very poor in working individually and in groups. They always rely on translation apps and sometimes choose answers randomly when they do not know the meaning of the test question. Besides, they are also more often impaired during the learning process from WhatsApp, Facebook, or Instagram messages or notifications on their respective smartphones. Another observation showed that students often needed focus during the learning process because they can move not from the need for using smartphones. Industry 4.0 comes as a new lifestyle, where everything will be easier to solve with one click. When tasks are given to them to do with a specific time, most of them have not been able to complete on time and are just busy playing smartphones, on other hand, the use of google translate is often used as a solution of doing tasks. Therefore, it is very difficult for them to feel challenged during the learning process. A phenomenon that was quite disturbing when they were issued listening tests. They tend to choose answers randomly rather than trying to understand the information contained in the listening text.

Various models, methods, and learning techniques were implemented, but it does not enough to solve those problems. The results of interviews with several teachers in the second semester showed that they needed treasures and variations of learning models that could keep up with the development of technology, conditions, and situations of learners. Therefore, a new learning model, method, or technique is needed to increase students' enthusiasm by engaging things that are very close to themselves such as their experience or habits as one of the main instruments in the learning process and also facilitate them to make smartphones as one of the best learning partners. Consequently, the utilization of mobile learning as one of the characteristics is to optimize learning and improve students' abilities and skills. The results of the study conducted by (Fuchs, n.d.; Grau \& Turula, n.d.; Lin, 2019; Thai et al., 2017) imply that students' abilities and skills are improving through flipped/blended learning.

The NURS teaching model is one of the learning models that is assumed to use as a solution to the problem. The NURS (Nature, Unique, Relevant, Situational) model is a learning model found by Nurming Saleh through the cross-cultural communication studies in the creation of cross-cultural German-language teaching materials. (Saleh et al., 2020) NURS is a didactic, constructively, metacognitive, humanly, intercultural, instructional, and technological-based learning procedure. This teaching model has seven steps. They are apperception, brainstorming of life experience based on the theme or topic of learning, opinion appreciation, explaining materials and giving instructions, discussion, making a creative presentation, and reflection.

Nature implies the empowerment of all things that are around learners, both inside and outside of them. In the context of language teaching, this aspect orients on facilitating the integration of ideas or concepts based on experience and things found in the learners ' support relating to the theme or topic of learning. This opinion relates to the results of study studies by (Hermann \& Bossle, 2020) state that learning from things that are in our area is a preliminary approach to knowing or understanding topological learning. In other ways, this approach can be to be 
one of the sources of ideas that will describe in a piece of information in the learning process. (Cantrell et al., 2017; Garg et al., 2019; Jung, 2019; Zou et al., 2015) argued that learning by appealing experience is an efficient approach to learning to improve one's ability and skills in the learning process.

Unique denotes the constructively, metacognitive, humanly, intercultural, instructional, and technological-based learning procedure. Learning center is a mental processes and empowering knowledge into potency, ability, and skill by using technological media and the instructional process, which are learning everywhere (from home or other places) and anytime. During the learning process, students will be the center of learning, and there will be various kinds of communication patterns as a representation of the person's level of ability and skill. This condition triggers your behavioral modifications to the respect of culture and differences, cherish, and help each other. So, it can be concluded that the learning outcome is not only the ability and skill of learners but also the founding of human values that are whole will be a memorable learning experience.

Relevant represents a relationship between the learning instruments and the needs and conditions of learners. Concerning language learning, this aspect is more implemented by the teacher in the materials and teaching books used in the learning process by lifting themes or learning topics that correspond to the conditions of life, experience, and level of the learners. Situational interprets as an aspect related to the development of science and technology. Currently, we are in the 4.0 industry that has an impact on the use of digital media. With the learning process, teachers should involve the technical in the learning process because such involvement can provide a new value and learning style for the students. The benefits of technology-based learning put forward by (Csikosova et al., 2012) learning through e-learning will optimize the skills and skill of learners included initiation, informing, explanation, resume, harmonization, encouragement, willingness for the compromise, and evaluation.

In light of the previous studies, the research questions of the present study are as following:

1. How to teach the German by the NURS teaching model?

2. Can the NURS teaching model improve German listening competencies of student?

\section{RESEARCH METHOD}

This study is a classroom action research (CAR) that adopts the Kemmis and Taggart design consisting of four steps (Manik, K., \& Gafur, A.,2016). They are planning, action, observation, and reflection. This study was in the German education department of the Faculty of Languages and Literature of UNM with 25 students in the second semester. Research instruments in this study include student activity sheet, and listening formative test. The test consists of three parts. Part 1 and 2 is a multiple-choice test, and part 3 is the true or false test. The data was examined by the researcher using percentage techniques. A student has completed the study when it has fulfilled the implemented minimum score of 65 or $65 \%$ at the German educational department at the Faculty of Language and Literature of Makassar State University as the curriculum standards of teaching. To find out the 
category of grades, the researchers adopted an assessment from the Goethe Institute. Perlmann-Balme \& Stoffers (2012) categorized the German predicate score of the test in this following table:

Table 1. Predicate score of Goethe Institute

\begin{tabular}{cc}
\hline Score & Predicate \\
\hline $90-100$ & very good \\
\hline $80-89$ & good \\
\hline $70-79$ & satisfy \\
\hline $60-69$ & legitimate \\
\hline $0-59$ & failed \\
\hline
\end{tabular}

\section{RESULT AND DISCUSSION}

\section{The NURS teaching model implementation}

\section{Planning}

At this step, the researcher prepares the learning instrument consisting of learning plans, student spreadsheets, and listening formative tests. The theme taught in this cycle is "Ab in den Urlaub" or holiday based on the Netzwerk A1 text book. Besides, the researcher has also prepared tools supporting learning activities and observation sheets for learning management. It was the same with the second and third circles. The teacher should find out the weakness of implementing the NURS teaching model and made it better in the next circle.

\section{Action}

This stage is identical to the implementation of the NURS teaching model in learning German and facilitating student listening competence through its seven teaching steps. Each cycle consists of three meetings and one meeting to test students' listening competencies. Learning began with an apperception activity in which there were several questions given to students to setback their understanding of the previous material, and the teacher seeks to prepare the student's mental and psychological to follow the learning process through Bryn gym and some other ice breaking. After that, the teacher checked the student's attendance. At the next step, students are asked to share their experiences with the theme of learning. At this step, about $60 \%$ of students have not been able to recount their experiences because they were still awkward and had limited German vocabulary. However, the teacher besides gave appreciation to them who have expressed their opinions and who became problems.

The core activity in the learning process in this first cycle was teaching and learning activities that demanded more extensive student activity and enthusiasm. The learning began with a holiday video on YouTube through an easy German vlog. Students were visibly confused and some smiled because of the beauty of the scenery and the attractions contained in the video when the students were watching the video. During the learning process, students were very busy with individual and group tasks to know their understanding of the listening text. After 
that, they made a creative presentation related to their responses to the content of the listening text. This situation is quite alarming because their enthusiasm during the task was very lacking. When they were making presentation projects, several students of the group were active. The final activity of the learning process using the NURS teaching model is reflection. In this step, teachers and students concluded together with the teaching material, and teachers gave students listening assignments using google classroom.

Teaching in the second with the same room and time with the previous circle. The beginning learning activity was equal with the three steps of the NURS teaching model that are apperception, brainstorming of life experience based on the theme or topic of learning, and giving appreciation. But students' enthusiasm has increased when they share their experiences following the learning theme. The information they tell us already includes several points, such as when, where, with whom, and how long they have been on vacation, in addition to the funny and memorable things that they experienced on vacation. The center learning activities are focused on providing materials using Edmodo. Students receive and missed listening text on the e-learning platform and then work individually and in groups to answer some questions related to the listening theme by using Quizizz. That was a way to make a smartphone as a student learning partner. After they worked on the quiz, they worked in groups and tried to infer the content of the listening through creative media by a presentation. Unlike the previous cycle, student's enthusiasm in this cycle has increased significantly, especially during presentations. Before the learning activity ended, the teacher provided some additional feedback and explanations regarding the results of the student presentation and gave follow-up assignments using Google Classroom.

Improving the competence of listening German students by using the NURS model is a didactic purpose that makes everything around the student as an instrument in the learning process. Test results in cycle two showed that the average student score was 61 . These grades fall into the legitimate category and do not meet the minimum standard criteria of learning achievement. Therefore, researchers provide a new treatment on the third cycle to improve the listening competence of students. Learning activities begin with ice breaking and invite students to move and train their focus. After that, the teacher submitted improvement advice regarding the task that was done by them in the previous week.

A picture illustrating a family holiday was shown to students after teachers checked their attendance. The apperceptions performed in this cycle are focused on students' efforts to write down as many vocabularies as they can about the images viewed through menti.com. The atmosphere of the class was so noisy because they raced to write down the word quickly. One of the funny things was when they wrote down a vocab as fast as possible, and it turned out to be the missing writing, so it becomes a take for other students to write properly. After the activity, participants were asked to tell about their family vacation by asking them to create five keywords that would be used as the main points when they told the story. Almost all the whole students have been able to tell a good and true story. As for 
the mistakes that often occur are the mispronunciation and use of German nouns, sometimes they are also mistaken in composing sentences using proper German tenses.

The hub activity in this third cycle is giving a listening text accompanied by a video for students. The text had questions in the form of multiple choices and incorrect correct tests to find out their understanding of the listening text. Learning activities are illustrated with individual-learning activities and groups through a creative presentation project delivered panelist in the learning process. The study ended with a reflection activity, in which the learner makes a conclusion and the teacher gives a briefing for preparing the test.

\section{Observation}

Observations of the NURS teaching model implementation are carried out through two ways that are listening ability test and learning management. The results of the listening ability test showed that student listening competence increased by $35.16 \%$ from the first cycle to the third cycle. The average value of their listening competencies in each circle is 46 (failed) in the first cycle, 61 (legitimate) in the second cycle, and 81.16 in the third cycle. Besides, observations are also conducted by two observers focused on three aspects, which are teaching and learning activity, time management, and enthusiasm of students and teachers. The observers are Muh. Anwar and Misnawaty Usman as the researcher team. The learning management data could be seen in this following table:

Table 2. Result of learning management observation of the NURS teaching model implementation on German listeing competence

\begin{tabular}{|c|c|c|c|c|c|}
\hline \multirow[t]{2}{*}{ No. } & \multirow[t]{2}{*}{ Observed Aspect } & \multicolumn{3}{|c|}{ Cycle } & \multirow[t]{2}{*}{ Average } \\
\hline & & I & II & III & \\
\hline \multirow[t]{10}{*}{$\mathbf{I}$} & $\begin{array}{l}\text { Observation of teaching and learning } \\
\text { activities }\end{array}$ & & & & \\
\hline & A. Introduction & & & & \\
\hline & 1. Motivating student & 3 & 3 & 4 & $3 \cdot 3$ \\
\hline & 2. Explaining the teaching aims & 2 & 3 & 4 & 3 \\
\hline & B. Main activities & & & & \\
\hline & $\begin{array}{l}\text { 1. Discussing the step of activities } \\
\text { with students }\end{array}$ & 2 & 3 & 4 & 3 \\
\hline & $\begin{array}{l}\text { 2. Leading students to do the } \\
\text { activities }\end{array}$ & 3 & 4 & 4 & 3.6 \\
\hline & $\begin{array}{l}\text { 3. Guiding students to argue the } \\
\text { results of learning activities in } \\
\text { the group }\end{array}$ & 3 & 4 & 4 & 3.6 \\
\hline & $\begin{array}{l}\text { 4. Providing opportunities for } \\
\text { students to present individual or } \\
\text { group learning outcomes }\end{array}$ & 2 & 3 & 4 & 3 \\
\hline & $\begin{array}{l}\text { 5. Guiding students to formulate } \\
\text { learning conclusions }\end{array}$ & 2 & 3 & 4 & 3 \\
\hline
\end{tabular}




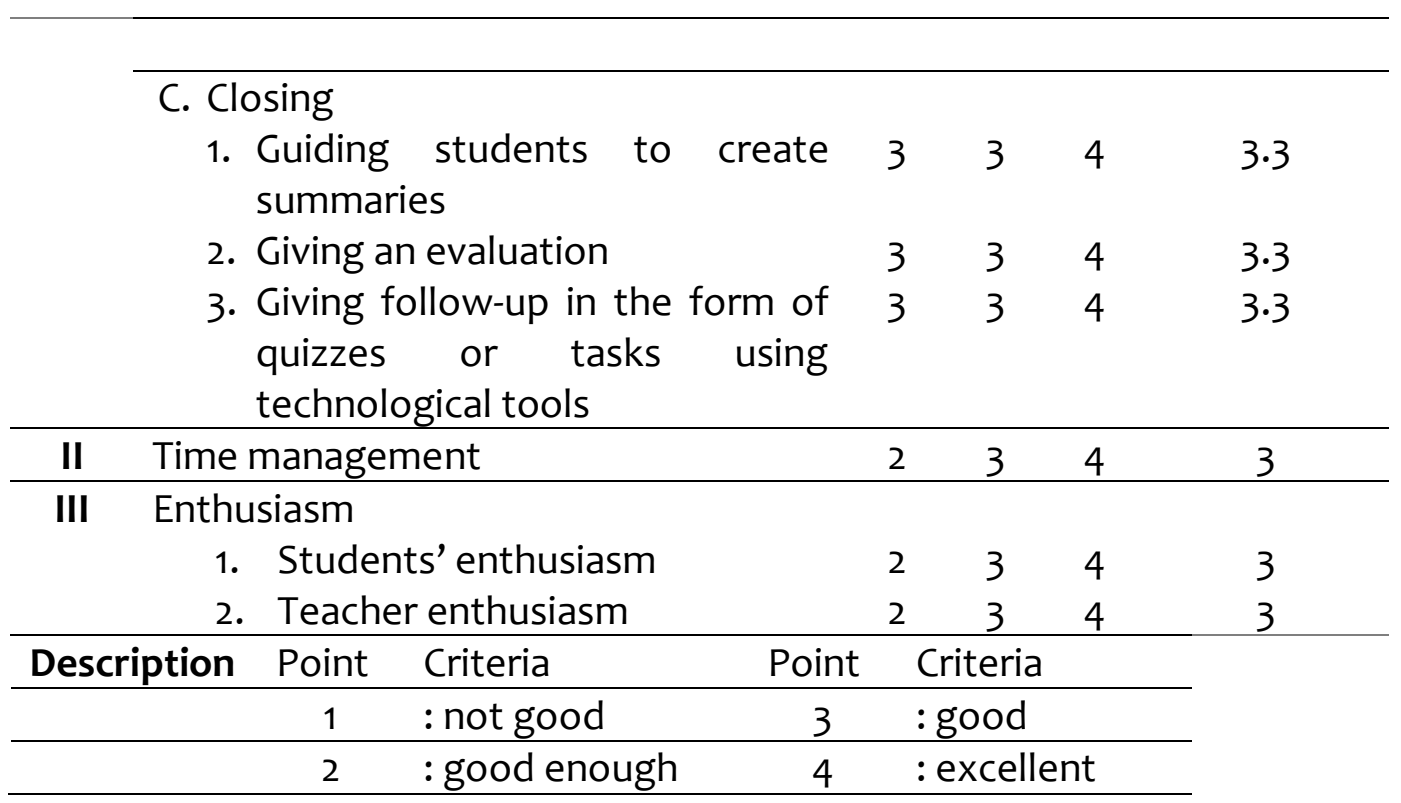

The observations showed that there was an improvement in the quality of learning in each cycle in both teaching and learning activities, time management, and enthusiasm of students and teachers. Teaching and learning activity consists of three parts, which are the introduction, main activities, and closing. The observations showed that motivating students and explaining the teaching aims as teaching and learning activities increased significantly from the first cycle with a value of 2, and it belongs good enough category to 4 as excellent in the third cycle. Not only an increase in the introduction but also in main activities, there is a significant increase in each circle. Discussing of activities step, leading to do something, and guiding to argue in the group show a significant development with an average of 3 , and it categorizes well. Also, an increase occurred in providing opportunities to present learning outcomes and guiding to formulate learning conclusions from a value of 2 in the first cycle to 4 in the third cycle. Closing as one aspect of teaching and learning activities also shows excellent improvement progress with an average value of 3 , and it belongs to a proper category. Closing as one aspect of teaching and learning activities shows excellent improvement progress with an average score of 3 , and it is in the proper category. The implementation of the NURS teaching model to improve the competence of listening German students is also supported by observations that show that time management and enthusiasm are aspects that increase in each cycle with an average score of 3, and it belongs to a good category.

The NURS teaching model has been implemented to improve student's German listening competencies as a model as well as a learning approach through three cycles that consisting of design, implementation, observation, and evaluation. Every cycle of this study consisted of three sessions. The results of the Germanlanguage skills test of the students could be seen in the following table: 
Table 3. Result of German Listening Test

\begin{tabular}{|c|c|c|c|c|}
\hline \multirow{2}{*}{$\begin{array}{c}\text { Part of Listening } \\
\text { Test }\end{array}$} & \multicolumn{3}{|c|}{ Mean score } & \multirow{2}{*}{$\begin{array}{l}\text { Increasing (\%) } \\
\mathbf{1}^{\text {st }}-3 \text { rd Circle }\end{array}$} \\
\hline & Circle 1 & Circle 2 & Circle 3 & \\
\hline Part 1 & 49 & 60 & 83 & $34 \%$ \\
\hline Part 2 & 50 & 65.5 & 79 & $29 \%$ \\
\hline Part 3 & 39 & 57.5 & 81.5 & $42.5 \%$ \\
\hline Average & 46 & 61 & 81.16 & $35.16 \%$ \\
\hline
\end{tabular}

Based on the previous information, it can be assumed that the NURS teaching model can improve student German listening competence by $35.16 \%$ with an average score of 81.16 and fall into the good category. On the other hand, the learning model also has a very significant positive impact on students and teachers in the learning process, both in teaching and learning activity, time management, and enthusiasm.

\section{Reflection}

This stage is the evaluation stage of development and improvement of learning quality by referring to the test results and assessment results of learning management in previous cycles. Some of the activities in the first cycle that are the study material at this stage are focused on teacher alignment related to learning objectives, discussion of learning steps, providing opportunities for students to present their work, guiding students to conclude learning, improve learning time, and enthusiasm of students and teachers.

In the second cycle, the activity-activities improved remarkably well that in the third circle, all aspects of learning management got an average score of 4 , and it is going to be into an excellent category. The listening skill is supported by the procedures of the NURS learning model during the learning process. When the teacher asked students for opinions relating to learning materials, which is the second procedure of the teaching model, they mostly reveal information based on their experience. This illustration is also assumed by (Cantrell et al., 2017; Garg et al., 2019; Jung, 2019; Zou et al., 2015), who revealed that experience as one of the learning resources is a way to optimize the potential of learners. Learning from experience is characteristic of the natural aspects of this learning model.

The third NURS learning model procedure also shows that the unique aspects of this learning model focused on optimizing and empowering knowledge and understanding to become a potential. At this step, students listen to the information contained in the audio and try to answer individual questions in the form of 10 multiple-choice questions. Before they answered the questions, they were asked to disclose information they understood from the audio. Empowerment of understanding and knowledge becomes a potential is the main foundation of constructivism learning theory as stated by (Hamid et al., 2019; Reusser \& Pauli, 2015) the process of constructivism is a process of forming the competence of learners through the optimization of their knowledge and understanding cognitively through the learning of individuals or groups. The uniqueness of this 
learning model is supported learning by an understanding of German culture derived from the information contained in the audio but still upholds its own culture as a medium of comparison and equality of understanding concepts. (Arslan, 2016; Dimova, 2011) suggests that understanding the culture of language learned by a student is a very useful manifestation of knowledge to help them understand information. Learning culture while learning a language is a unique thing that can make learners as multicultural human beings.

Flipped-based learning is one of the uniqueness of this learning model. During the learning process, students facilitated online and offline learning. Online learning is supported by the use of online learning platforms such as google classroom and Edmodo. Students are very enthusiastic about completing assignments and quizzes online. They were also given instructions to practice listening exercises outside the classroom and discussed before they learned any new material. Flipped-based learning adopts a blended learning design that combines face-to-face and technology-based learning. (Awidi \& Paynter, 2019; Chen et al., 2014; Chilingaryan \& Zvereva, 2017) revealed that flipped-based learning is an instructional learning design that combines learning outside the classroom and in the classroom as an integration that involves learners as the center point of learning through using technology as a learning partner.

Relevant and situational are quite important aspects of the NURS teaching model by presenting and selecting listening themes and materials. Teachers pay close attention to the students' needs and pay attention to the relevance of the theme, vocabulary, grammar, language level funds of the students taught. This aspect is supported by the situation of learners according to the development of science and technology that impacts their lifestyle, learning style, and habits, especially those related to their comfort zone. Students of the second semester in 2020 are too busy themselves with some applications on their respective smartphones. This situation is the primary mission carried out by teachers and can be an obstacle for students in improving listening competencies if teachers are not able to take advantage of various applications as learning partners and make smartphones not only as a medium that accelerates and facilitates all kinds of activities in one click but can also be the best German language learning partner.

\section{CONCLUSION}

The NURS teaching model is a didactic, constructively, metacognitive, humanly, intercultural, instructional, and technological-based learning procedure and has seven steps to implement. They are apperception, brainstorming of life experience based on the theme or topic of learning, opinion appreciation, explaining materials and giving instructions, discussion, making a creative presentation, and reflection. This model was implemented to improve German listening competence of student at German educational program at the faculty of language and literature at Makassar state University. The study result shows that the NURS teaching model can improve students' German listening competence by $35.16 \%$ with an average score of 81.16 and fall into the good category. On the other hand, the learning model also has a very significant positive impact on students and 
teachers in the learning process, both in teaching and learning activity, time management, and enthusiasm.

\section{REFERENCES}

Arslan, S. (2016). An Analysis of Two Turkish EFL Books in Terms of Cultural Aspects. Procedia - Social and Behavioral Sciences, 232, 217-225. https://doi.org/10.1016/j.sbspro.2016.10.049

Awidi, I. T., \& Paynter, M. (2019). The impact of a flipped classroom approach on student learning experience. Computers \& Education, 128, 269-283. https://doi.org/10.1016/j.compedu.2018.09.013

Cantrell, M. A., Franklin, A., Leighton, K., \& Carlson, A. (2017). The Evidence in Simulation-Based Learning Experiences in Nursing Education and Practice: An Umbrella Review. Clinical Simulation in Nursing, 13(12), 634-667. https://doi.org/10.1016/j.ecns.2017.08.004

Chen, Y., Wang, Y., Kinshuk, \& Chen, N.-S. (2014). Is FLIP enough? Or should we use the FLIPPED model instead? Computers \& Education, 79, 16-27. https://doi.org/10.1016/j.compedu.2014.07.004

Chilingaryan, K., \& Zvereva, E. (2017). Methodology of Flipped Classroom as a Learning Technology in Foreign Language Teaching. Procedia - Social and Behavioral Sciences, 237, 1500-1504. https://doi.org/10.1016/j.sbspro.2017.02.236

Csikosova, A., Teplicka, K., \& Senova, A. (2012). Communication and Humanization of University Education Through E-Learning. Procedia - Social and Behavioral Sciences, 46, 2978-2982. https://doi.org/10.1016/j.sbspro.2012.05.600

Dimova, V. (2011). Education and Culture. Procedia - Social and Behavioral Sciences, 15, 2357-2359. https://doi.org/10.1016/j.sbspro.2011.04.107

Fuchs, C. (n.d.). Critical incidents and cultures-of-use in a Hong Kong-Germany telecollaboration. Language Learning, 24.

Garg, R., Oh, E., Naidech, A., Kording, K., \& Prabhakaran, S. (2019). Automating Ischemic Stroke Subtype Classification Using Machine Learning and Natural Language Processing. Journal of Stroke and Cerebrovascular Diseases, 28(7), 2045-2051. https://doi.org/10.1016/j.jstrokecerebrovasdis.2019.02.004

Grau, M. K., \& Turula, A. (n.d.). Experiential learning of telecollaborative competences in pre-service teacher education. Language Learning, 18.

Hamid, M. A., Hilmi, D., \& Mustofa, S. (2019). Pengembangan Bahan Ajar Bahasa Arab Berbasis Teori Belajar Konstruktivisme Untuk Mahasiswa. Journal of Arabic Studies, 15.

Hermann, R. R., \& Bossle, M. B. (2020). Bringing an entrepreneurial focus to sustainability education: A teaching framework based on content analysis. Journal of Cleaner Production, 246, 119038. https://doi.org/10.1016/j.jclepro.2019.119038

Jung, S. (2019). Semantic vector learning for natural language understanding. Computer Speech \& Language, 56, 130-145. https://doi.org/10.1016/j.csl.2018.12.008

Lin, Y.-T. (2019). Impacts of a flipped classroom with a smart learning diagnosis system on students' learning performance, perception, and problem solving 
ability in a software engineering course. Computers in Human Behavior, 95, 187-196. https://doi.org/10.1016/j.chb.2018.11.036

Manik, K., \& Gafur, A. (2016). Penerapan model Two Stay Two Stray berbantuan multimedia untuk meningkatkan aktivitas dan hasil belajar IPS. Harmoni Sosial: Jurnal Pendidikan IPS, 3(1), 39-49.

Perlmann-Balme, M., \& Stoffers, M. (2012). Goethe-Zertifikat A1 Start Deutsch 1: Prüfungsziele, Testbeschreibung (2. aktualisierte Auflage). Goethe-Institut.

Reusser, K., \& Pauli, C. (2015). Co-constructivism in Educational Theory and Practice. In International Encyclopedia of the Social \& Behavioral Sciences (pp. 913-917). Elsevier. https://doi.org/10.1016/B978-0-08-097086-8.92026-9

Saleh, N., Rijal, S., \& Mannahali, M. (2020, November). Model Pembelajaran NURS dalam Keterampilan Menulis Bahasa Jerman. In Seminar Nasional Pengabdian Kepada Masyarakat.

Thai, N. T. T., De Wever, B., \& Valcke, M. (2017). The impact of a flipped classroom design on learning performance in higher education: Looking for the best "blend" of lectures and guiding questions with feedback. Computers \& Education, 107, 113-126. https://doi.org/10.1016/j.compedu.2017.01.003

Zhang, Q., \& Kou, Q. (2012). The Course Research for the Software Program Based on the Constructivism Teaching Theories. Physics Procedia, 25, 2294-2297. https://doi.org/10.1016/j.phpro.2012.03.386

Zou, F., Wang, L., Hei, X., \& Chen, D. (2015). Teaching-learning-based optimization with learning experience of other learners and its application. Applied Soft Computing, 37, 725-736. https://doi.org/10.1016/j.asoc.2015.08.047. 